\title{
Environmental influences on the spatial and temporal distribution of the puffer fish Sphoeroides greeleyi and Sphoeroides testudineus in a Brazilian subtropical estuary
}

\author{
Luís Fernando Fávaro ${ }^{1,2}$, Elton Celton de Oliveira ${ }^{2,3}$, \\ Augusto de Oliveira Brunow Ventura ${ }^{2}$ and Nelsy Fenerich Verani ${ }^{4}$
}

The spatial and temporal distribution of Sphoeroides greeleyi and Sphoeroides testudineus were established from collections (biological material and environmental data) conducted on a monthly basis from May 2000 to April 2001 in intertidal areas along the north-south axis of the estuarine complex of Paranaguá, Paraná State. In addition to characterizing a north-south spatial gradient, which fluctuates seasonally, the variation in the abiotic factors made possible the division of the estuary into three regions: north, central and south. Spatially, it was found that the number of individuals declines significantly for both species in the north-south direction of the estuary. Moreover, significant differences were found in the size of individuals across the estuarine regions. The largest $S$. greeleyi individuals were caught in the north, as well as the smallest $S$. testudineus individuals. The catches with the highest numbers of puffer fish occurred from late spring to early autumn, coinciding with the occurrence of specimens of smaller size and lower mean body mass. The results indicate that spatial and temporal variations in the environment impact the distribution patterns of both puffer fish species, suggesting that the co-occurrence of closely related species functions as a modulating factor in that distribution.

A distribuição espacial e temporal de Sphoeroides greeleyi e Sphoeroides testudineus foram estabelecidas a partir de coletas (material biológico e dados ambientais) realizadas mensalmente de maio/2000 a abril/2001 em áreas intertidais, no eixo norte-sul, do complexo estuarino de Paranaguá, Estado do Paraná. A variação dos fatores abióticos coletados, além de caracterizar um gradiente espacial, no sentido norte-sul, que varia sazonalmente, possibilitou a divisão do estuário em três regiões: norte, central e sul. Espacialmente, verificou-se para ambas as espécies que o número de indivíduos decresce, significativamente, no sentido norte-sul estuarino. Ainda, foram encontradas diferenças significativas no porte dos indivíduos entre as regiões do estuário, no norte ocorreram os maiores indivíduos de $S$. greeleyi e os menores de $S$. testudineus. As maiores capturas dos baiacus ocorreram do final da primavera ao início do outono, coincidindo com a ocorrência de exemplares de menor tamanho e de menor massa corporal média. Os resultados indicam que as variações espaciais e temporais do ambiente afetam os padrões de distribuição de ambas as espécies de baiacus, sugerindo que a co-ocorrência de espécies aparentadas age como um fator modulador nesta distribuição.

K ey words: Tetraodontidae, Estuarine-residents, Closely related species, Abundance, Length structure.

${ }^{1}$ Departamento de Biologia Celular, Setor de Ciências Biológicas, Universidade Federal do Paraná (UFPR). Caixa Postal: 19031, 81531-990 Curitiba, PR, Brazil. lufavaro@ufpr.br

${ }^{2}$ Laboratório de Reprodução e Comunidade de Peixes, Departamento de Biologia Celular - UFPR.

${ }^{3}$ Pós-Graduando (Bolsista CAPES) do Programa em Ecologia e Conservação - UFPR. elton_oliveirabio@yahoo.com.br

${ }^{4}$ Departamento de Hidrobiologia, Centro de Ciências Biológicas e da Saúde, Universidade Federal de São Carlos, Rodovia Washington Luíz, Km 235, 13565-905 São Carlos, SP, Brazil.dnfv@power.ufscar.br 


\section{Introduction}

Studies of fish population dynamics and structure make possible the understanding of biological processes and their relationships with abiotic factors, as well as adding to the knowledge on how species utilize their environment (Whitfield \& Elliott, 2002). Since the estuarine-resident ichthyofauna goes through its entire life cycle in the estuarine environment (Blaber, 2002), it reproduces in that environment and takes active part in the trophic equilibrium. Consequently, its biology and population structure may be altered if any environmental imbalance factor is present (Whitfield \& Elliott, 2002). Therefore, studies conducted with these species become necessary in order to understand their dynamics in the estuarine environment.

Two species of estuarine-resident puffer fish, Sphoeroides greeleyi Gilbert, 1900 and Sphoeroides testudineus (Linnaeus, 1758), closely related yet genetically distinct (Noleto et al., 2007), have ample distribution in the Eastern Atlantic and are frequent and abundant along the Brazilian coast (Figueiredo \& Menezes, 2000). They are representative of the Tetraodontidae family, characterized by two dentigerous plates in the upper jaw and two in the lower jaw. They feed mostly on gastropods, bivalves and crustaceans (Targett, 1978) and preferably dwell in bays and estuaries, where they are considered to be important in the trophic equilibrium (Duncan \& Szelistowski, 1998; Schultz et al., 2002).

These species show a high frequency and abundance in the estuarine complex of Paranaguá, Brazil (Vendel et al., 2002; Spach et al., 2003; Felix et al., 2006), where the present work was conducted. They have broad physiological tolerance (Prodocimo \& Freire, 2001, 2004; Prodocimo et al., 2008) and use the same food resources (Chiaverini, 2008). However, they exhibit differences regarding the body size of individuals. The maximum size recorded for $S$. greeleyi was $17 \mathrm{~cm}$, while it was $25 \mathrm{~cm}$ for S. testudineus (Figueiredo \& Menezes, 2000).

According to Wilson (1975), body size in closely related species is a determinant factor in the differentiation of niches. Knouft (2003) tested this prediction and demonstrated that morphological divergences are more pronounced when two or more closely related species are in sympatry, which is the case of the species $S$. greeleyi and S. testudineus in the estuarine complex of Paranaguá.

Over time, the competition for resources may have been determinant in the modulation of morphological and/or behavioral characteristics in these species, which enabled them to occur in sympatry now, a condition in which the exploration and partitioning of resources facilitate coexistence (Schluter, 2000).

Although the species S. greeleyi and S. testudineus are closely related, highly abundant and have significant ecological importance, their population dynamics has never been the object of studies, nor have these species been included in predictions concerning niche theories. Thus, gathering information on the distribution patterns of $S$. greeleyi and $S$. testudineus in estuarine areas could establish a key starting point for studies on the dynamics and cooccurrence of closely related estuarine species.

Therefore, based on the spatial and temporal variation in the biotic and abiotic data, the present study attempted to characterize the environment and evaluate the distribution of both species through data on abundance, body size and ratio of juveniles to adults.

\section{Material and Methods}

\section{Study Area}

The estuarine complex of Paranaguá is located in the northern portion of the coastal plain of Paraná State, between coordinates $25^{\circ} 15^{\prime} \mathrm{S} 48^{\circ} 45^{\prime} \mathrm{W}$ and $25^{\circ} 35^{\prime} \mathrm{S} 48^{\circ} 10^{\prime} \mathrm{W}$, and is divided into two main axes: east-west and north-south (Ipardes, 2001).

According to the Köppen classification, the climate of the region is mesothermal humid subtropical (Cfa) with warm summers and lacking a well-defined dry season. Nevertheless, Lana et al. (2001) established for this estuarine system that the rainy season occurs from late spring to early autumn, and the dry season extends from late autumn to late winter. The same author also reported that the mean air humidity of the region is $85 \%$, with mean annual rainfall of 2,500 $\mathrm{mm}$. According to Maack (1981), the mean air temperature of the warmest month is above $22^{\circ} \mathrm{C}$ and below $18{ }^{\circ} \mathrm{C}$ for the coldest month.

\section{Sampling Procedure}

In order to establish environmental characterization, temperature, salinity, $\mathrm{pH}$, dissolved oxygen and water transparency values were recorded. These environmental variables were obtained by means of a mercury thermometer, a refractometer, a pH meter, Winkler's method (Grasshoff et al., 1983) and the Secchi disk, respectively. Data collection and fish sampling were conducted on the same occasions, except for dissolved oxygen, whose concentrations were measured in the laboratory, at a later time.

Between May 2000 and April 2001, monthly collections of biological material were carried out with a beach seine net (30.0 m long, $2.0 \mathrm{~m}$ high, $3.0 \mathrm{~m}$ mouth, $0.5 \mathrm{~cm}$ mesh between adjacent knots). Two consecutive 50-metre hauls were performed at each one of the eight sampling sites (P1, P2, P3, P4, P5, P6, P7 and P8) located in intertidal areas on the northsouth axis of the estuarine complex of Paranaguá (Fig. 1). In the months of December 2000 and April 2001, collections at the sampling site P2 were not performed on account of a strong ebb tide.

In the laboratory, the specimens were identified according to Figueiredo \& Menezes (2000). Subsequently, for each sampling site, a random subsampling of 60 individuals per species was undertaken, when necessary. These individuals were measured for morphometric data concerning total length (Lt), in centimeters, and total weight (Wt), in grams; excess specimens were only counted and weighed. From this 


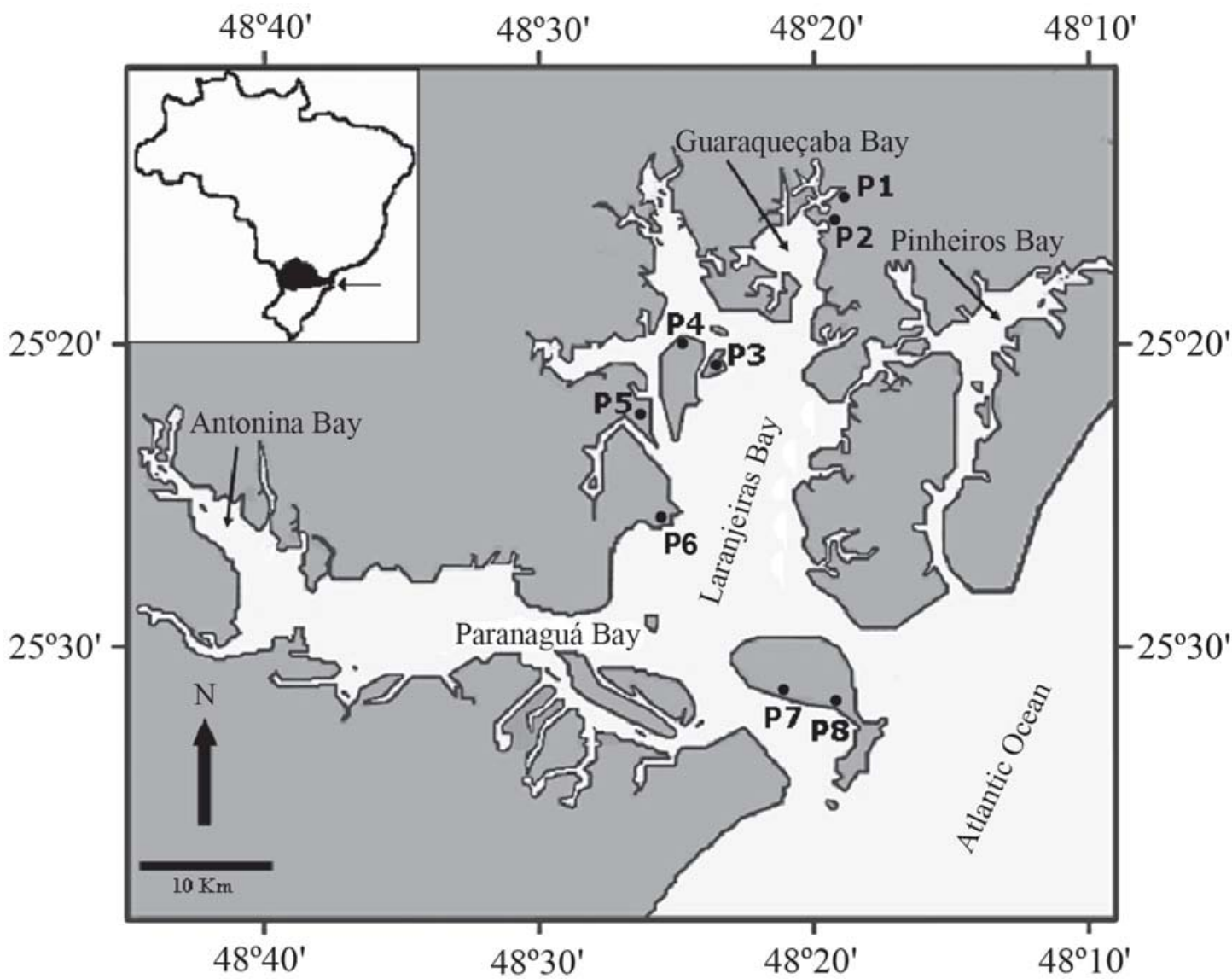

Fig. 1. Map of the estuarine complex of Paranaguá, northern shore of the State of Paraná, Brazil, locating the sampling sites.

subsample, 30 randomly sampled specimens of each species were designated for reproductive analysis, the aim of which was to identify the gonadal development stages in order to estimate the ratio of juveniles to adults.

Voucher specimens were deposited in the fish collection at the Museu de História Natural do Capão da Imbuia, Curitiba, PR (MHNCI) (Sphoeroides testudineus: MHNCI 11764; Sphoeroides greeleyi: MHNCI 11765).

\section{Data Analysis}

The environmental data were analyzed through the principal component analysis (PCA) and either parametric (ANOVA) or nonparametric (Kruskal-Wallis) analyses of variance. For ANOVA, Fisher's least significant differences (LSD) a posteriori test was used; for Kruskal-Wallis, the Mann-Whitney test was employed a posteriori. These analyses were undertaken with the aim of exploring and determining the spatial and temporal (seasonal) patterns of the environment, as well as describing its relationships with the biotic data.

Spearman's correlation was used, for both species, in order to investigate whether the variation in the number of individuals collected was correlated with the sampling sites and/or the environmental factors which determined spatial variations. The data on the number of individuals were transformed into $\log _{10}$ to minimize the effect of discrepant captures.

Total length (Lt) and total weight (Wt) data for both species were submitted to the nonparametric analysis of variance to investigate possible spatial variations in the size of individuals. Whenever differences were detected in the body size of individuals along the estuary, the Mann-Whitney test was applied to the data in order to quantify and establish those differences.

Prior to the utilization of the parametric or nonparametric analyses of variance, the data were tested for normality through Shapiro-Wilk test, and the homogeneity of variances was assessed by means of Levene's test. When the data showed normality and homogeneity of variances, the parametric analysis of variance was the method of choice; when the data were not normally distributed, and yet exhibited homogeneity of variances, the nonparametric analysis of variance was used. Data transformations were performed whenever necessary in order to meet the requirements of each statistical test (Quinn \& Keough, 2002).

For both species, temporal analyses were carried out considering the clustered sites. Analyses included monthly catch rate, mean body mass, length structure and ratio of juveniles to adults.

Monthly catch rates, expressed in percent, were determined 
by the relation between the number of specimens captured monthly and the total number of individuals captured in the study period. In order to assess the body mass structure, the mean monthly body mass was used. It was obtained through the relation between total body mass and the number of individuals captured each month. Length structure was established with the individuals whose morphometric data were recorded, and was evaluated seasonally through the absolute and percent frequency values of the individuals distributed within the length classes, as defined by Sturges's Postulate (Sokal \& Rohlf, 1981).

For the monthly determination of juvenile and adult individuals, macroscopic and histological analyses of the gonads were performed. Juveniles were defined as those specimens presenting gonads at the immature stage (A), and adults, the specimens whose gonads were at the stages: maturation (B), mature (C), partially spawned (SD) or spawned/ spent (D). Histological characterization was based on the works of Schultz et al., 2002 and Rocha et al., 2002, who studied the reproduction of these species in the same estuarine system.

In the present work, the seasons of the year were defined as: spring, from September to November; summer, from December to February; autumn, from March to May, and winter, from June to August.

\section{Results}

\section{Environmental Characterization}

The first two axes of the environmental data ordination resulting from the PCA showed an explanation of $77 \%$ of the total variation. Component I explained $54 \%$ of that variation, while component II explained 23\%. Salinity, pH, dissolved oxygen and water transparency showed a positive correlation with component I, revealing an increasing gradient of these variables north to south of the estuary. Temperature showed a highly negative correlation with component II, thus verifying the seasonality of the environmental data (Table 1, Fig. 2).

Based on the spatial separation observed in the PCA, three regions were defined along the north-south axis of the estuary: north, comprising sites P1 and P2; central, containing sites P3, P4 and P5, and south, including sites P6, P7 and P8.

Table 1. Value of each vector along components I and II of the principal component analysis (PCA) conducted for the abiotic factors measured on the north-south axis of the estuarine complex of Paranaguá, Paraná State.

\begin{tabular}{lcc}
\hline \multicolumn{1}{c}{ Factor } & Component I & Component II \\
\hline Salinity & 0.519 & 0.099 \\
Temperature $\left({ }^{\circ} \mathrm{C}\right)$ & -0.120 & -0.870 \\
$\mathrm{pH}$ & 0.546 & -0.301 \\
Dissolved oxygen $(\mathrm{ml} / \mathrm{L})$ & 0.445 & 0.283 \\
Transparency $(\mathrm{m})$ & 0.469 & -0.250 \\
Eigenvalues & 2.66 & 1.16 \\
Explained variation $(\%)$ & 54 & 23 \\
\hline
\end{tabular}

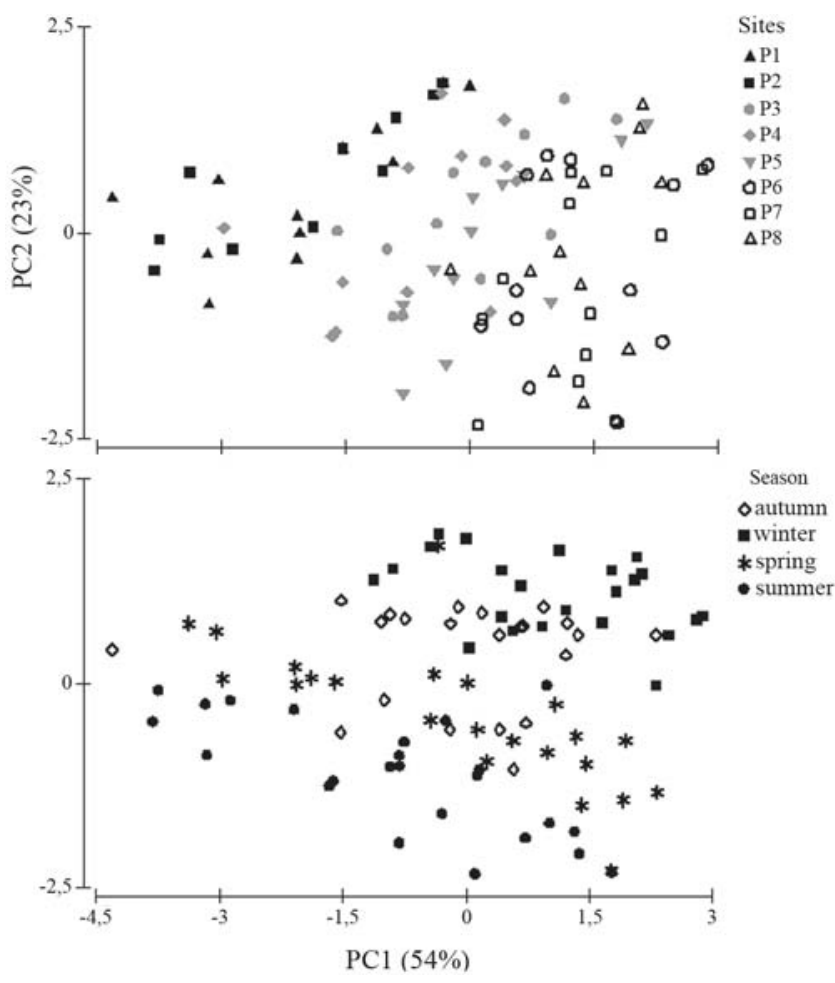

Fig. 2. Graphic representation of the Principal Component Analysis (PCA) conducted for the sampling sites and for the seasons of the year on the north-south axis of the estuarine complex of Paranaguá, Paraná State.

Salinity, pH and transparency showed significant differences across the three regions. The highest means for these factors were observed in the south, followed by the central and north regions of the estuary. Dissolved oxygen showed significant differences only between the north and south regions, whereas temperature did not exhibit significant differences across the regions. However, it was demonstrated that the temperature means throughout the seasons were significantly different. Besides temperature, salinity, dissolved oxygen and transparency also exhibited seasonal variations (Table 2). The results found in these univariate analyses corroborated the information produced by the PCA.

\section{Spatial Variation}

The species S. greeleyi and S. testudineus were captured at all sampling sites, totaling 3,008 and 1,896 individuals captured, respectively. The catches with the highest number of individuals occurred in the north and central regions of the estuary for both species (Table 3). The finding that the number of individuals captured decreases in the north-south direction of the estuary was supported by the significant negative correlations between the number of individuals and the explaining factors sampling sites, $\mathrm{pH}$, dissolved oxygen, water transparency and salinity, the latter showing the strongest correlation (Table 4).

Total length and total weight data showed that the largest 
Table 2. Results of the comparisons for environmental factors between the estuarine regions and the seasons of the year, on the north-south axis of the estuarine complex of Paranaguá, Paraná State. $F=$ ANOVA results, $H=$ Kruskal-Wallis results; $L S D=$ results of Fisher's least significant difference test; $U=$ results of Mann-Whitney test; * significant $(\mathrm{p}<0.05)$, n.s = nonsignificant; $\mathrm{S}=$ south region; $\mathrm{C}=$ central region; $\mathrm{N}=$ north region; $\mathrm{Su}=$ summer, $\mathrm{Au}=$ autumn, $\mathrm{Wi}=$ winter and $\mathrm{Sp}$ = Spring.

\begin{tabular}{|c|c|c|c|c|}
\hline \multirow{2}{*}{ Factor } & \multicolumn{2}{|c|}{ Region } & \multicolumn{2}{|c|}{ Season } \\
\hline & $F / H$ & $L S D / U$ & $F / H$ & $L S D / U$ \\
\hline Salinity & $\mathrm{H}=50.78^{*}$ & $\mathrm{~S}>\mathrm{C}>\mathrm{N}$ & $\mathrm{F}=7.73^{*}$ & $\mathrm{Au}, \mathrm{Wi}>\mathrm{Sp}, \mathrm{Su}$ \\
\hline Temperature & n.s & - & $\mathrm{H}=70.38 *$ & $\mathrm{Su}>\mathrm{Sp}>\mathrm{Au}>\mathrm{Wi}$ \\
\hline $\mathrm{pH}$ & $\mathrm{H}=66.31^{*}$ & $\mathrm{~S}>\mathrm{C}>\mathrm{N}$ & n.s & - \\
\hline Dissolved oxygen & $\mathrm{F}=10.35^{*}$ & $\mathrm{~S}, \mathrm{C}>\mathrm{N}$ & $\mathrm{F}=9.11 *$ & $\mathrm{Wi}>\mathrm{Sp}, \mathrm{Au}>\mathrm{Su}$ \\
\hline Transparency & $\mathrm{F}=27.48^{*}$ & $\mathrm{~S}>\mathrm{C}>\mathrm{N}$ & $\mathrm{F}=4.95^{*}$ & Wi, $\mathrm{Sp}>\mathrm{Su}, \mathrm{Au}$ \\
\hline
\end{tabular}

Table 3. Number of S. greeleyi and S. testudineus individuals caught at each sampling site on the north-south axis of the estuarine complex of Paranaguá, Paraná State. Sites P1 and P2 corresponded to the north region, sites P3, P4 and P5 to the central region, and sites P6, P7 and P8 represented the south region of the estuary.

\begin{tabular}{lccccccccc}
\hline & \multicolumn{8}{c}{ Region/Sites } & \\
\cline { 2 - 8 } & \multicolumn{1}{c}{ North } & \multicolumn{4}{c}{ Central } & \multicolumn{3}{c}{ South } & \\
\hline \multicolumn{1}{c}{ Species } & P1 & P2 & P3 & P4 & P5 & P6 & P7 & P8 & Total \\
Sphoeroides greeleyi & 800 & 45 & 765 & 404 & 679 & 211 & 65 & 39 & 3,008 \\
Sphoeroides testudineus & 738 & 226 & 167 & 55 & 261 & 396 & 37 & 16 & 1,896 \\
\hline
\end{tabular}

Table 4. Results of Spearman's correlation $\left(r_{s}\right)$ between the number of individuals collected and explaining factors: sampling sites, salinity, $\mathrm{pH}$, dissolved oxygen and water transparency on the north-south axis of the estuarine complex of Paranaguá, Paraná State. * significant $(\mathrm{p}<0.05)$.

\begin{tabular}{lccc}
\hline \multirow{2}{*}{ Factor } & S. greeleyi & & \multicolumn{1}{c}{ S. testudineus } \\
\cline { 2 - 2 } \multicolumn{1}{c}{$r_{\mathrm{s}}$} & & $r_{\mathrm{s}}$ \\
\hline Sites & $-0.43^{*}$ & & $-0.44^{*}$ \\
Salinity & $-0.65^{*}$ & & $-0.50^{*}$ \\
pH & $-0.28^{*}$ & & $-0.33^{*}$ \\
Dissolved oxygen & $-0.45^{*}$ & & $-0.35^{*}$ \\
Transparency & $-0.37^{*}$ & & $-0.26^{*}$ \\
\hline
\end{tabular}

individuals of $S$. greeleyi were found, significantly, in the north, followed by the south and central regions. For $S$. testudineus, the largest individuals occurred in the south and central regions, while the smallest were found in the north. In addition, it was observed that the two species occurred with very similar sizes in the north region (Table 5).

\section{Temporal Variation}

The two species were caught in all months of the study period. The catches of $S$. greeleyi and S. testudineus amounted to $7,035.76 \mathrm{~g}$ and $17,716.60 \mathrm{~g}$, respectively. The period in which the largest catches and the lowest mean body mass values were recorded was from November to April (Fig. 3).
The seasonal distribution of S. greeleyi in length classes showed that the smallest individuals, ranging between 1.1 and $4.9 \mathrm{~cm}$, occurred more in the spring and summer. Specimens ranging between 5.0 and $7.5 \mathrm{~cm}$ were collected mostly in the autumn, while individuals with total lengths between 7.6 and $15.1 \mathrm{~cm}$ were more abundant in the winter. The same analysis, when conducted for S. testudineus, demonstrated that the specimens of the lower length classes (between 1.2 and $9.2 \mathrm{~cm}$ ) occurred throughout the year. However, individuals collected in the summer and autumn predominated in these classes. Specimens as large as $9.3 \mathrm{~cm}$ or larger occurred more abundantly in the spring (Fig. 4).

Based on the percent distribution of juvenile and adult individuals, it was found that $S$. greeleyi showed a high frequency of juvenile individuals in the period from November to April (late spring to mid-autumn) and of adult individuals between June and October (winter and spring). For $S$. testudineus, the presence of juvenile individuals was observed throughout the study period, while adult individuals were most frequent during the spring (Fig. 5).

The analyses employed to assess the temporal variation of S. greeleyi and S. testudineus were mutually corroborative, which indicates a relationship between the number of individuals collected, their body size and the time of the year.

\section{Discussion}

\section{Environmental Characterization}

In addition to characterizing the environment, the environmental analysis conducted in the present work proved a relationship between the spatial and temporal variation of abiotic factors and the population distribution of the species S. greeleyi and S. testudineus.

The increasing gradient of the environmental factors in the north to south direction of the estuarine complex of Paranaguá was mainly influenced by $\mathrm{pH}$, although the variables salinity, transparency and dissolved oxygen also contributed relevantly. According to Ipardes (2001), the area defined in the present work as the north region of the estuarine complex of Paranaguá has well-developed mangroves, low hydrodynamics and intense anthropic activity, such as deforested areas, pasturelands and arable lands. These characteristics, along with decreased marine influence, the high precipitation rate of the region (Lana et al., 2001) and the input of autochthonous and allochthonous materials from the influx of freshwater from continental drainage, favor organic matter buildup in that region, which explains the low values found for the environmental variables. According to Esteves (1998), aquatic environments with input of autochthonous and allochthonous materials exhibit lower $\mathrm{pH}$ values owing to the higher concentrations of dissolved organic acids.

On the other hand, the area defined as the south region in the present study shows greater marine influence, which imparts a higher level of energy (Blaber, 2000) and, 
Table 5. Results of the Kruskal-Wallis test $(H)$ and the Mann-Whitney test $(U)$ a posteriori for the comparison of total length (Lt) and total weight (Wt) values of S. greeleyi and S. testudineus across the estuarine regions (North (N), Central (C) and South (S)) on the north-south axis of the estuarine complex of Paranaguá, Paraná State. For this analysis, the data were transformed into $\log _{10}$. The medians and quartiles for total length and total weight of the two species indicate the variation in these attributes in the three regions of the estuary. * significant $(\mathrm{p}<0.05)$.

\begin{tabular}{lcccccc}
\hline \multirow{2}{*}{ Species } & \multirow{2}{*}{ Attribute } & \multirow{2}{*}{$H$} & \multicolumn{2}{c}{ Median + Quartiles by Region } & \multirow{2}{*}{$U$} \\
\cline { 4 - 6 } \cline { 4 - 6 } S. greeleyi & $\mathrm{Lt}$ & $85.65^{*}$ & $2.73(2.49-2.80)$ & $2.62(2.41-2.72)$ & $2.66(2.53-2.73)$ & $\mathrm{N}>\mathrm{S}>\mathrm{C}$ \\
& $\mathrm{Wt}$ & $113.04^{*}$ & $3.52(2.87-3.76)$ & $3.14(2.61-3.42)$ & $3.25(2.88-3.48)$ & $\mathrm{N}>\mathrm{S}>\mathrm{C}$ \\
\multirow{4}{*}{ S. testudineus } & $\mathrm{Lt}$ & $76.71^{*}$ & $2.72(2.52-2.81)$ & $2.79(2.67-2.91)$ & $2.81(2.68-2.93)$ & $\mathrm{S}, \mathrm{C}>\mathrm{N}$ \\
& $\mathrm{Wt}$ & $65.86^{*}$ & $3.51(2.94-3.78)$ & $3.68(3.37-4.03)$ & $3.73(3.37-4,10)$ & $\mathrm{S}, \mathrm{C}>\mathrm{N}$ \\
\hline
\end{tabular}

consequently, increased hydrodynamics to that region, resulting in higher $\mathrm{pH}$, transparency, salinity and dissolved oxygen values. According to Odum (2004), ocean waters have alkaline $\mathrm{pH}$, around 8.0, and lower concentrations of organic matter when compared with estuarine regions. Azevedo et al. (2007), working with the demersal ichthyofauna in Sepetiba Bay - RJ, found spatial variations in salinity, transparency, dissolved oxygen and depth, obtaining the lowest values in the inner estuarine areas and the highest values in the estuarine waters with stronger marine influence.

In the present work, the seasonal variation of abiotic

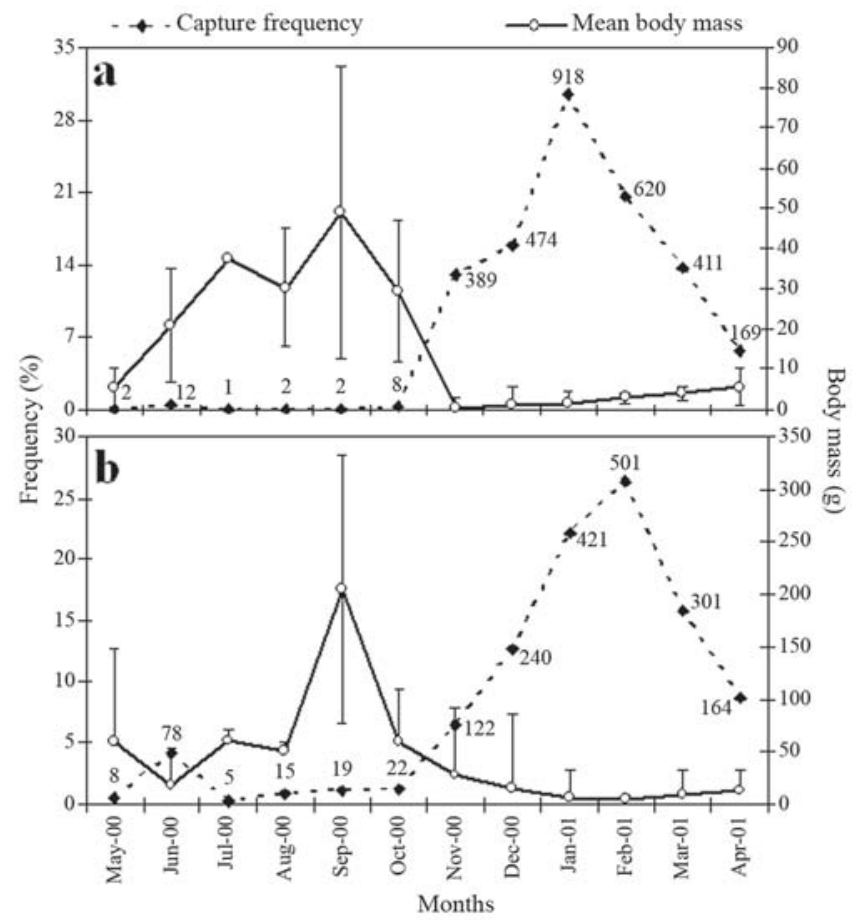

Fig. 3. Monthly ratio between catch rate and mean body mass of S. greeleyi (a) and S. testudineus (b) on the north-south axis of the estuarine complex of Paranaguá, Paraná State. The numbers on the catch rate curve refer to absolute frequency and the deviation bars on the mean body mass curve indicate standard deviation. factors was mostly determined by the variations in water temperature - which, according to Vega-Cendejas \& Santillana (2004), is one of the factors with a direct influence on the distribution patterns of biological communities.

\section{Spatial Variation}

The population distribution of S. greeleyi and S. testudineus responded to the spatial variation of the environmental factors, since both species exhibited a decline in the number of individuals in the north-south direction of the estuary. This finding is related to habitat selection patterns, which are
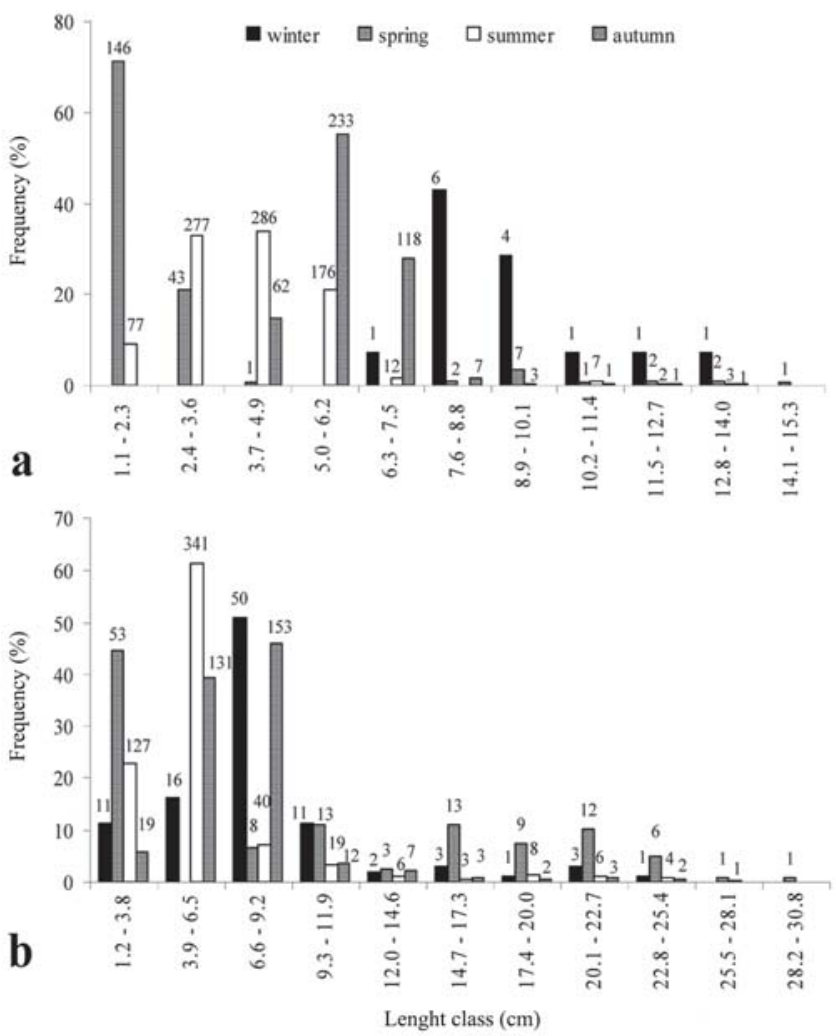

Fig. 4. Seasonal distribution of the percent frequency of $S$. greeleyi (a) and S. testudineus (b) individuals in length classes on the north-south axis of the estuarine complex of Paranaguá, Paraná State. The numbers indicated above the bars refer to absolute frequency. 


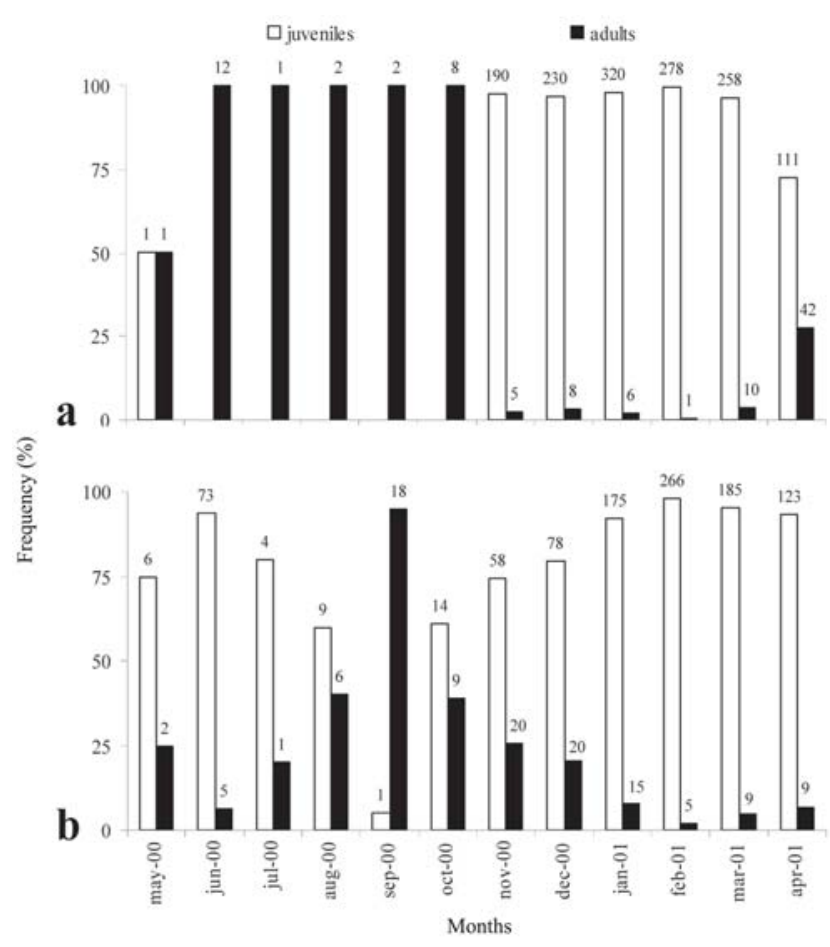

Fig. 5. Monthly distribution of juvenile and adult individuals of S. greeleyi (a) and S. testudineus (b) on the north-south axis of the estuarine complex of Paranaguá, Paraná State. The numbers indicated above the bars refer to absolute frequency.

controlled or regulated by a set of physiological characteristics, prey availability, foraging success, competitor density, predation pressure and spawning sites (Baltz et al., 1998).

In this study, salinity was the environmental variable that correlated more strongly with the variation in the number of individuals, a fact which corroborates the findings of Blaber (1997), who reported that most estuarine fishes are eurihaline. However, the distribution of a given species seems to depend on the degree of its physiological tolerance. Prodocimo \& Freire (2001, 2004) and Prodocimo et al. (2008), studying the osmoregulatory ability of $S$. greeleyi and S. testudineus, reported that the species are eurihaline and exhibit similar ability for plasma osmolality and salt water ionic regulation.

Therefore, the ability of the species to tolerate a wide variation in salinity, in conjunction with the existence of more secluded areas and well-developed mangroves in the north and central regions favor the occurrence of both species, probably by providing adequate locations for foraging, reproduction and shelter. Our data are corroborated by Giarrizzo \& Krumme (2008), who related the high abundance of Tetraodontidae species to the proximity of the Amazon River mouth, reporting that truly estuarine species are found in regions of lower salinity, while marine or marine-estuarine species preferably occur in regions of greater marine influence. The importance of the puffer fish of the Tetraodontidae family in the maintenance and equilibrium of the trophic chain in mangrove areas was reported by Targett (1978), Ducan \&
Szelistowski (1998) and Krumme et al. (2007).

The differences in size of S. greeleyi and S. testudineus individuals found across the regions of the estuary probably occurred as a result of the interplay of three factors: 1- differing productivity across the regions of an estuary; 2- distinct habitat selection patterns in individuals of the same species but different sizes; 3- the problematic concerning the cooccurrence of closely related species.

Although the species $S$. greeleyi is known to reach smaller sizes than S. testudineus (Figueiredo \& Menezes, 2000), specimens of the two species with comparable sizes occurred in the north region in the present work, while a divergence of sizes was observed in the south. Thus, it is suggested that higher productivity areas, such as the north region of the estuarine complex of Paranaguá, more easily support the cooccurrence of closely related species, since competition must be minimized by the great availability of resources. In estuarine areas with lower productivity, on the other hand, closely related species seek to maximize size differences so as to reduce competition and allow coexistence. The assumptions made herein, despite not being supported by the data and deserving experimental investigations, are in line with Dando (1984), who reported that the most productive regions in an estuary are those exhibiting the lowest salinity levels ( 1 to 20), where high densities of juvenile fish are found. Furthermore, the same author describes that competition is minimized in those regions as a result of greater resource availability and the behavioral and/or morphological variation in the species, which eventually reveal differences in their diet as well as their spatial and temporal distribution.

\section{Temporal Variation}

In this study, it was found that the largest catches of $S$. greeleyi and S. testudineus occurred in the period from November to April, and the smallest, between May and October. Spach et al. (2003) and Felix et al. (2006) reported an increase in the catch rate of puffer fish during the period when temperatures are higher and, according to the community studies conducted by Godefroid et al. (1997) and Santos et al. (2002), there is an upward tendency in the abundance of fishes in the warmest periods of the year.

Rocha et al. (2002) and Schultz et al. (2002), who studied the reproductive biology of $S$. greeleyi and $S$. testudineus in the estuarine complex of Paranaguá, established that the peak of reproductive activity for both species is in October (spring). The spawning season extends from October to February, while recruitment occurs over the subsequent months, corresponding to the summer and autumn. This information, along with temporal variations in mean body mass, length structure and the ratio of juvenile to adult individuals found in the present study, reflect the response of both populations to the reproductive and recruitment processes. According to Jobling (1995), such processes are regulated by variations in temperature and photoperiod in temperate and subtropical regions.

In the present work, the characteristics of the environment made it possible to divide the north-south axis of the estuary into three regions which revealed distinct distribution patterns 
for the populations of S. greeleyi and S. testudineus in terms of abundance and size of individuals. Seasonally, variations in temperature and photoperiod influenced the reproductive and the recruitment processes of both species, leading to changes in catch rates, body size and the ratio of juveniles to adults.

\section{Literature Cited}

Azevedo, M. C. C., F. G. Araújo, A. G. Cruz-Filho, A. L. M. Pessanha, M. A. Silva \& A. P. P. Guedes. 2007. Demersal fishes in a tropical bay in southeastern Brazil: Partitioning the spatial, temporal and environmental components of ecological variation. Estuarine Costal and Shelf Science, 75: 468-480.

Baltz, D. M., J. W. Fleeger, C. F. Rakocmski \& J. N. Maccall. 1998. Food, density, and microhabitat: factors affecting growth and recruitment potential of juvenile saltmarsh fishes. Environmental Biology Fishes, 53: 89-103.

Blaber, S. J. M. 1997. Fish and Fisheries of Tropical Estuaries. London, Chapman \& Hall, 458p.

Blaber, S. J. M. 2000. Tropical Estuarine Fishes: Ecology, Exploitation and Conservation. London, Blackwell Science, 372p.

Blaber, S. J. M. 2002. 'Fish in hot water': the challenges facing fish and fisheries research in tropical estuaries. Journal of Fish Biology, 61(Supplement A): 1-20.

Chiaverini, A. P. 2008. Ecologia trófica de Sphoeroides testudineus Linnaeus, 1758 e Sphoeroides greeleyi Gilbert, 1900 da Gamboa do Perequê, Pontal do Sul, Paraná, Brasil. Unpublished Ph.D. Dissertation Universidade Federal do Paraná, Curitiba, PR, 54p.

Dando, P. R. 1984. Reproduction in Estuarine Fish. Pp. 155-170. In: Potts, G. W. \& R. J. Wootton (Eds.). Fish Reproduction: Strategies and Tactics. San Diego, Academic Press, 424p.

Duncan, R. S. \& W. A. Szelistowski. 1998. Influence of puffer predation on vertical distribution of mangrove litorinids in the Gulf of Nicoya, Costa Rica. Oecologia, 117: 433-442.

Esteves, F. A. 1998. Fundamentos de Limnologia. Rio de Janeiro, Interciência, $2^{\text {nd }}$ ed., 602p.

Felix, F. C., H. L. Spach, C. W. Hackradt, P. S. Moro \& D. C. Rocha. 2006. Abundância sazonal e a composição da assembléia de peixes em duas praias estuarinas da Baía de Paranaguá, Paraná. Revista Brasileira de Zoociências, 8(1): 35-47.

Figueiredo, J. L. \& N. A. Menezes. 2000. Manual de peixes marinhos do sudeste do Brasil. VI. Teleostei (5). São Paulo, Museu de Zoologia da Universidade de São Paulo, 116p.

Giarrizzo, T. \& U. Krumme. 2008. Heterogeneity in intertidal fish fauna assemblages along the world's longest mangrove area in northern Brazil. Journal of Fish Biology, 72: 773-779.

Godefroid, R. S., M. Hoffstaeter \& H. L. Spach. 1997. Structure of the fish assemblage in the surf zone beach at Pontal do Sul, Paraná. Nerítica, 11: 77-93.

Grasshoff, K., M. Ehrhardt \& K. Kremling. 1983. Methods of seawater analysis. $2^{\text {nd }}$ edition. Weinheim, Verlag Chemie, 419p.

Ipardes - Instituto Paranaense de Desenvolvimento Econômico e Social. 2001. Zoneamento da área de proteção ambiental de Guaraqueçaba. Curitiba, Ipardes, 150p.

Jobling, M. 1995. Environmental biology of fishes. London, Chapman \& Hall, 455p.

Knouft, J. H. 2003. Convergence, divergence, and the effect of congeners on body size ratios in stream fishes. Evolution, 57(10): 2374-2382.

Krumme, U., H. Keuthen, U. Saint-Paul \& W. Villwock. 2007. Contribution to the feeding ecology of the banded puffer fish Colomesus psittacus (Tetraodontidae) in north Brazilian mangrove creeks. Brazilian Journal of Biology, 67(3): 383-392.

Lana, P. C., E. Marone, R. M. Lopes \& E. Machado. 2001. The subtropical estuarine complex of Paranaguá Bay, Brazil. Pp. 131-145. In: Seeliger, U. \& B. Kjerfre (Eds.). Coastal marine ecosystems of Latin America. Berlim, Springer, 360p.

Maack, R. 1981. Geografia física do Estado do Paraná. Curitiba, BDT/UFPR/IBPT, 350p.

Noleto, R. B., M. R.Vicari, R. R. Cipriano, R. F. Artoni \& M. M. Cestari. 2007. Physical mapping of 5S and 45S rDNA loci in pufferfishes (Tetraodontiformes). Genetica, 130(2): 133-138.

Odum, E. P. 2004. Fundamentos de ecologia. Rio de Janeiro, Guanabara Koogan, $7^{a}$ ed., 927p.

Prodocimo, V. \& C. A. Freire. 2001. Ionic regulation in aglomerular tropical estuarine pufferfishes submitted to sea water dilution. Journal of Experimental Marine Biology and Ecology, 262: 243-253.

Prodocimo, V. \& C. A. Freire. 2004. Estuarine puffer fishes (Sphoeroides testudineus and S. greeleyi) submitted to sea water dilution during ebb tide: a field experiment. Marine and Freshwater Behaviour and Physiology, 37: 1-5.

Prodocimo, V., C. F. Souza, C. Pessini, L. C. Fernandes \& C. A. Freire. 2008. Metabolic substrates are not mobilized from the osmoregulatory organs (gills and kidney) of the estuarine pufferfishes Sphoeroides greeleyi and S. testudineus upon shortterm salinity reduction. Neotropical Ichthyology, 6(4): 613-620.

Quinn, G. P. \& M. J. Keough. 2002. Experimental design and data analysis for biologists. New York, Cambridge University Press, 520p.

Rocha, C., L. F. Fávaro \& H. L. Spach. 2002. Biologia reprodutiva de Sphoeroides testudineus (Linnaeus), (Pisces, Osteichthyes, Tetraodontidae) da gamboa do Baguaçu, Baía de Paranaguá, Paraná, Brasil. Revista Brasileira de Zoologia, 19(1): 57-63.

Santos, C., R. Schwarz Jr, J. F. Oliveira Neto \& H. L. Spach. 2002. A Ictiofauna em duas planícies de maré do setor euhalino da Baía de Paranaguá, PR. Boletim do Instituto de Pesca, 28(1): 49-60.

Schluter, D. 2000. Ecological character displacement in adaptive radiation. The American Naturalist, 156: 4-16.

Schultz, Y. D., L. F. Fávaro \& H. L. Spach. 2002. Aspectos reprodutivos de Sphoeroides greeleyi (Gilbert), Pisces, Osteichthyes, Tetraodontidae, da gamboa do Baguaçu, Baía de Paranaguá, Paraná, Brasil. Revista Brasileira de Zoologia, 19(1): 65-76.

Sokal, R. R. \& F. J. Rohlf. 1981. Biometry. New York, W. H. Freeman, 859p.

Spach, H. L., C. Santos \& R. S. Godefroid. 2003. Padrões temporais na assembléia de peixes da gamboa do Sucuriú, Baía de Paranaguá, Brasil. Revista Brasileira de Zoologia, 20(4): 591-600.

Targett, T. E. 1978. Food resource partitioning by the puffer fishes Sphoeroides spengleri and S. testudineus from Biscayne Bay, Florida. Marine Biology, 49: 83-91.

Vega-Cendejas, M. E. \& M. H. Santillana. 2004. Fish community structure and dynamics in a coastal hypersaline lagoon: Rio Lagartos, Yucatan, México. Estuarine, Coastal and Shelf Science, 60: 285-299.

Vendel, A. L., H. L. Spach, S. G. Lopes \& C. Santos. 2002. Structure and Dynamics of Fish Assemblages in a Tidal Creek Environment. Brazilian Archives of Biology and Technology, 45(3): 365-373.

Whitfield, A. K. \& M. Elliott. 2002. Fishes as indicators of environment and ecological changes within estuaries: a review of progress and some suggestions for the future. Journal of Fish Biology, 61(Supplement A): 229-250.

Wilson, D. S. 1975. The adequacy of body size as a niche difference. The American Naturalist, 109: 769-784. 